\title{
PERBEDAAN pH SALIVA SEBELUM DAN SETELAH BERKUMUR DENGAN REBUSAN BUNGA ROSELLA PADA MAHASISWA JURUSAN KEPERAWATAN GIGI BUKITTINGGI
}

\author{
Zulfikri , Fiki Rivaldo Putra \\ (Jurusan Kesehatan gigi Politeknik Kesehatan Kemenkes Padang)
}

\begin{abstract}
Polyphenols and flavonoids of roselle ( Hibiscus sabdariffa $L$ ) acts as an antiviral, antioxidant and antibacterial that can affect bacteria and increase the $\mathrm{pH}$ of saliva in the oral cavity. The purpose of this study to determine differences in the $\mathrm{pH}$ of saliva before and after rinsing with stew rosella The design is a quasi-experimental study with pretest and posttest. The population in this study Dental students from the Department of Nursing. The sampling technique is purposive sampling. Data collected by direct observation and examination of the salivary $\mathrm{pH}$. Analysis of the data used using paired t test.Results showed before rinsing with rosella flower stew, average salivary $\mathrm{pH} 6.6$ (acidic) and after rinsing with rosella flower stew average salivary $p H$ to 7.0 (neutral). Statistical test Paired t test showed $p$ value $=0.00<0.05$. Conclusion of the study that there is a significant difference between the $\mathrm{pH}$ of saliva before and after rinsing with stew rosella. Suggested to the research subjects to use a mouthwash of natural materials such as stew rosella to maintain oral health.
\end{abstract}

Keywords : salivary $\mathrm{pH}$, on average, rinse, stew rosella

\section{PENDAHULUAN}

Kebutuhan global saat ini untuk pencegahan alternatif dan pilihan pengobatan untuk penyakit mulut yang aman, efektif dan ekonomis semakin meningkat. Hal ini disebabkan oleh beberapa faktor, diantaranya adalah meningkatnya insidensi penyakit dan meningkatnya resistensi bakteri patogen terhadap antibiotik yang saat ini digunakan. Namun di negara berkembang juga turut mempengaruhi peningkatan permintaan pengobatan yang lebih aman, efektif dan ekonomis. Oleh karena itu, pencarian produk alternatif terus dilakukan. Salah satu produk alami yang memiliki banyak manfaat adalah rosella (Prestiyanti, 2014).

Rosella (Hibiscus sabdariffa $L$ ) adalah tanaman hias dari keluarga sejenis kembang sepatu. Tanaman ini dapat hidup di daerah tropis maupun subtropis dan dikenal sebagai teh herbal. Bunga rosella mengandung polifenol, beberapa vitamin, mineral serta 18 macam asam amino. Beberapa penelitian menunjukkan bahwa polifenol memiliki aktivitas sebagai antivirus, antioksidan serta antibakteri. Bunga rosella mampu menghambat perkembangan bakteri streptococcus sanguisyang menjadi pemicu terbentuknya plak gigi(Prestiyanti, 2014).

Berdasarkan hasil penelitian terdahulu, ditemukan bahwa: 1. Rebusan kelopak bunga rosella mempunyai daya hambat terhadap pertumbuhan bakteri staphylococcus aereus dan escherichia coli (Nisa, 2013), 2. Diperoleh bahwa adanya pengaruh obat kumur dari bahan bunga rosella untuk menghambat pembentukan koloni bakteri dan 
candida albicans pada mahkota akrilik karena memiliki efek antifungi dan peneliti juga menjelaskan bahwa seduhan rebusan kelopak bunga rosella dapat dijadikan salah satu alternatif antibakteri dan antiplak (Machmud, 2013), 3. Adanya efektivitas obat kumur ekstrak bunga rosella dalam menghambat pertumbuhan plak (Sari, 2012), dan 4. Air rebusan bunga rosella dapat menghambat pertumbuhan koloni bakteri pada sikat gigi. Tujuan penelitian ini adalah untuk mengetahui perbedaan $\mathrm{pH}$ saliva sebelum dan setelah berkumur dengan rebusan bunga rosella pada mahasiswa Jurusan Keperawatan Gigi.

\section{METODE PENELITIAN}

Metode ini menggunakan metode eksperimental semu dengan rancangan pretest dan posttest. Penelitian ini dilaksanakan di kampus Jurusan Keperawatan Gigi Bukittinggi. Populasi pada penelitian ini adalah seluruh mahasiswa Jurusan Keperawatan Gigi. Sampel pada penelitian ini berjumlah 30 orang. Teknik pengambilan sampel yang digunakan adalah "purposive sampling"yaitu pengambilan sampel berdasarkan pertimbangan pribadi peneliti sendiri, dengan kriteria inklusi : 1) Bersedia mengisi informed consent, 2) Hadir disaat penelitian.

\section{HASIL PENELITIAN}

1. $\mathrm{pH}$ saliva responden sebelum berkumur dengan rebusan bunga rosella dapat dilihat pada tabel 5 berikut ini:

\begin{tabular}{lc}
$\begin{array}{l}\text { Tabel 1. Rata-rata pH Saliva Sebelum Berkumur dengan Rebusan } \\
\text { Bunga Rosella }\end{array}$ \\
\begin{tabular}{lc}
\hline Responden & 30 orang \\
& \\
\hline $\begin{array}{l}\text { Rata-rata pH saliva sebelum } \\
\text { berkumur dengan rebusan }\end{array}$ & \\
bunga \\
rosella
\end{tabular} \\
\hline
\end{tabular}

Berdasarkan tabel 1, dapat diketahui bahwa rata-rata $\mathrm{pH}$ saliva sebelum berkumur dengan rebusan bunga rosella pada mahasiswa Jurusan Keperawatan Gigi Bukittinggi yaitu 6,6 . Hal ini menyatakan bahwa rata-rata $\mathrm{pH}$ saliva responden bersifat asam.

2. $\mathrm{pH}$ saliva responden setelah berkumur dengan rebusan bunga rosella dapat dilihat pada tabel 2 berikut ini:

Tabel. 2 Rata-rata pH Saliva Setelah Berkumur dengan Rebusan Bunga Rosella

\begin{tabular}{lc}
\hline Responden & 30 orang \\
\hline $\begin{array}{l}\text { Rata-rata pH saliva setelah berkumur } \\
\text { dengan rebusan bunga rosella }\end{array}$ & 7,0 \\
\hline
\end{tabular}


Berdasarkan tabel 2, dapat diketahui bahwa rata-rata $\mathrm{pH}$ saliva setelah berkumur dengan rebusan bunga rosella pada mahasiswa Jurusan Keperawatan Gigi Bukittinggi yaitu 7,0. Hal ini menyatakan bahwa rata-rata $\mathrm{pH}$ saliva responden bersifat netral.

3. Perbedaan rata-rata $\mathrm{pH}$ saliva sebelum dan setelah berkumur dengan rebusan bunga rosella dapat dilihat pada tabel 3 berikut ini:

\begin{tabular}{lc}
$\begin{array}{l}\text { Tabel.3 Perbedaan Rata -rata pH Saliva Sebelum dan Setelah Berkumur } \\
\text { dengan Rebusan Bunga Rosella }\end{array}$ \\
\hline $\begin{array}{l}\text { Sebelum berkumur dengan } \\
\text { rebusan bunga rosella }\end{array}$ & 6,6 \\
$\begin{array}{l}\text { Setelah berkumur dengan rebusan } \\
\text { bunga rosella }\end{array}$ & 7,0 \\
$\begin{array}{l}\text { Perbedaan pH saliva sebelum dan } \\
\text { setelah berkumur dengan rebusan } \\
\text { bunga rosella }\end{array}$ & 0,4 \\
\hline
\end{tabular}

Berdasarkan tabel 3, dapat diketahuibahwa rata-rata $\mathrm{pH}$ saliva sebelum berkumur dengan rebusan bunga rosella pada mahasiswa Jurusan Keperawatan Gigi Bukittinggi yaitu 6,6 (asam). Setelah berkumur dengan rebusan bunga rosella pada mahasiswa Jurusan Keperawatan Gigi Bukittinggi terjadi peningkatan sebesar 0,4 sehingga rata-rata $\mathrm{pH}$ saliva responden menjadi 7,0 (netral).

Uji t (paired sample $t$ test) dilakukan untuk mengetahui perbedaan rata-rata $\mathrm{pH}$ saliva sebelum dan sesudah berkumur dengan rebusan bunga rosella pada mahasiswa Jurusan Keperawatan Gigi Bukittinggi tahun 2016, dapat dilihat pada tabel 4 berikut ini:

Tabel.4 Hasil Uji Statistik Perbedan pH Saliva Sebelum dan Setelah Berkumur dengan Rebusan Bunga Rosella

\section{pH Sebelum-pH Sesudah \\ Mean}

Standar Deviasi
$-.40667$

.46826

\begin{tabular}{ll}
\hline $\mathbf{T}$ & -4.757 \\
Signifikan & .000 \\
\hline
\end{tabular}

Berdasarkan tabel 4, dapat diketahui bahwa angka signifikan $p$ value $(0,00)<0,05$, maka dapat disimpulkan bahwa hipotesis nihil ( $\mathrm{Ho}$ ) ditolak dan hipotesis alternative $(\mathrm{Ha})$ diterima, jadi dapat diartikan bahwa ada perbedaan yang signifikan antara rata-rata $\mathrm{pH}$ saliva sebelum dan setelah berkumur dengan rebusan bunga rosella pada mahasiswa Jurusan Keperawatan Gigi Bukittinggi. 


\section{PEMBAHASAN}

\section{pH saliva responden sebelum berkumur dengan rebusan bunga rosella}

Berdasarkan hasil penelitian yang telah dilakukan pada subyek penelitian diperoleh $\mathrm{pH}$ saliva sebelum berkumur dengan rebusan bunga rosella rata-rata $\mathrm{pH}$ saliva responden yaitu 6,6 . Ini menyatakan bahwa rata-rata $\mathrm{pH}$ saliva responden dalam keadaan asam. Menurut peneliti hal ini kemungkinan disebabkan karena penelitian di lakukan pada saat siang hari setelah waktu istrihat, Keasaman saliva sangat berpengaruh setelah makan, $\mathrm{pH}$ saliva bersifat asam seperempat jam setelah makan tetapi akan normal kembali dalam waktu 30 60 menit. Makanan yang mengandung karbohidrat dan sukrosa serta tidak membersihkan mulut atau berkumur-kumur setelah mengkonsumsi makanan tersebut maka bakteri di dalam rongga mulut akan memfermentasikan karbohidrat dan sukrosa menjadi asam sehingga $\mathrm{pH}$ saliva di dalam mulut bersifat asam (Amerogen, 1991). Berdasarkan penelitian terdahulu mengenai $\mathrm{pH}$ saliva bahwa setelah mengkonsumsi makanan yang mengandung karbohirat dan sukrosa rata-rata $\mathrm{pH}$ saliva bersifat asam (Azalia, 2012).

\section{pH saliva responden setelah berkumur dengan rebusan bunga rosella}

Berdasarkan hasil penelitian tentang perbedaan $\mathrm{pH}$ saliva setelah berkumur dengan rebusan bunga rosella pada responden, rata-rata $\mathrm{pH}$ saliva setelah berkumur dengan Menurut peneliti ini terjadi karena adanya zat antibakteri seperti polifenol dan flavonoid dari rebusan bunga rosella yang mampu menghambat pertumbuhan dan mengurangi jumlah koloni bakteri di dalam rongga mulut.

Hasil penelitian ini sesuai dengan teori bahwa rebusan bunga roselladengan kandungan polifenol dan flavonoid sebagai antibakteri dapat menghambat pertumbuhan bakteri di dalam rongga mulut, karena polifenol dan flavonoid mampu membentuk senyawa kompleks dengan protein melalui ikatan hidrogen, polifenol bekerja dengan cara mendenaturasi protein sel dan merusak membran plasma bakteri, kemudian adanya pelepasan protein dan enzim dari dalam sel oleh saponin, sehingga tanin mampu menghambat produksi enzim oleh bakteri, berikatan dengan dinding sel serta menghancurkan membrane (Azalia, 2012), jika bakteri dipengaruhi maka $\mathrm{pH}$ saliva akan meningkat (netral), karena bakteri tersebut tidak mampu memfermentasikan karbohirat dan sukrosa menjadi asam (Sofrata, 2010).

Berdasarkan penelitian terdahulu tentang pengaruh obat kumur dari bahan bunga rosella untuk menghambat pertumbuhan koloni bakteri dan candida albicans pada mahkota akrilik menyatakan bahwa rebusan bunga rosella dapat dijadikan salah satu alternatif 
antibakteri dan antiplak (NN, 2015).

Hasil penelitian tentang perbedaan $\mathrm{pH}$ saliva sebelum dan setelah berkumur dengan rebusan bunga rosella pada mahasiswa Jurusan Keperawatan Gigi Bukittinggi menunjukkan bahwa rata-rata $\mathrm{pH}$ saliva sebelum berkumur dengan rebusan bunga rosella pada mahasiswa Jurusan Keperawatan Gigi Bukittinggi yaitu 6,6, sedangkan rata-rata $\mathrm{pH}$ saliva setelah berkumur dengan rebusan bunga rosella pada mahasiswa Jurusan Keperawatan Gigi Bukittinggi yaitu 7,0, artinya ada peningkatan rata-rata $\mathrm{pH}$ saliva setelah berkumur dengan rebusan bunga rosella pada mahasiswa Jurusan Keperawatan Gigi Bukittinggi sebesar 0,4 .

Makanan yang mengandung karbohidrat dan sukrosa serta tidak membersihkan mulut atau berkumur-kumur setelah mengkonsumsi makanan tersebut maka $\mathrm{pH}$ saliva di dalam mulut bisa menjadi asam oleh bakteri di dalam rongga mulut (Amerogen, 1991). Selain itu, hasil metabolisme karbohidrat oleh mikroorganisme dalam rongga mulut juga akan menghasilkan asam yang akan memicu proses demineralisasi enamel dan dentin, sehingga akan memicu terjadinya karies (Sofrata, 2010). Adanya zat antibakteri dari rebusan bunga rosella yang mampu menghambat pertumbuhan dan mengurangi jumlah koloni bakteri di dalam rongga mulut, sehingga bakteri tersebut tidak mampu menfermentasikan karbohirat dan sukrosa menjadi asam. Dengan demikian pH saliva akan bersifat netral.

Hasil penelitian ini jika dilihat dengan uji statistik (pairet $t$ test). Angka signifikan $\mathrm{p}$ value $(0,00)<0,05$, dapat diketahui bahwa hipotesis nihil $(\mathrm{Ho})$ di tolak dan hipotesis alternatif $(\mathrm{Ha})$ diterima, artinya ada perbedaan yang signifikan antara $\mathrm{pH}$ saliva sebelum dan setelah berkumur dengan rebusan bunga rosella pada mahasiswa Jurusan Keperawatan Gigi Bukittinggi. Menurut peneliti hal ini dapat terjadi karena kandungan polifenol dari rebusan bunga rosella berfungsi sebagai antibakteri dengan cara mendenaturasi protein sel dan merusak membran plasma bakteri (Sari, 2012). sehingga bakteri tersebut tidak dapat menfermentasi karbohidrat menjadi asam (Sofrata, 2010). Oleh karena itu akan terjadi peningkatan $\mathrm{pH}$ saliva karena bakteri yang menfermentasikan karbohidrat menjadi asam telah di pengaruhi oleh kandungan polifenol yang terdapat pada rebusan bunga rosella.

\section{SIMPULAN DAN SARAN}

Berdasarkan hasil penelitian dapat disimpulkan bahwa rata-rata $\mathrm{pH}$ saliva sebelum berkumur dengan rebusan bunga rosella pada mahasiswa Jurusan Keperawatan Gigi Bukittinggi yaitu 6,6, artinya rata-rata $\mathrm{pH}$ saliva mahasiswa Jurusan Keperawatan Gigi Bukittinggi dalam keadaan asam, rata-rata $\mathrm{pH}$ saliva sesudah berkumur dengan rebusan bunga rosella pada mahasiswa Jurusan Keperawatan Gigi Bukittinggi yaitu 7.0, artinya ratarata $\mathrm{pH}$ saliva mahasiswa Jurusan Keperawatan Gigi Bukittinggi dalam keadaan netral, ada perbedaan $\mathrm{pH}$ saliva sebelum dan setelah berkumur dengan rebusan bunga rosella pada 
mahasiswa Jurusan Keperawatan Gigi Bukittinggi.

Disarankan bagi responden dan pembaca bahwa rebusan bunga rosella dapat dijadikan sebagai obat kumur yang berbahan dasar alami.

\section{DAFTAR PUSTAKA}

Amerongen, dkk. 1991, Ludah dan Kelenjar Ludah Arti Bagi Kesehatan Gigi. Abyono R, editor. Yogyakarta:GadjahMada University Press;

Azalia, YolaTania. 2012, Pengaruh Berkumur-kumur dengan Rebusan Kulit Manis terhadap pH Saliva pada Siswa Kelas IV \& V SDN 07 Limo Kampung Kota PayakumbuhTahun 2012.[KTI] Bukittinggi: JurusanKeperawatan Gigi;

Machmud, Edy., Dharmautama, Moh., Sutono, Erwin. 2013, Efektifitas Berkumur Menggunakan Obat Kumur Dari Bahan Bunga Rosella (Hibiscus sabdariffa L.) Untuk Menghambat Pembentukan Koloni Bakteri Dan Candida Albicans Pada Mahkota Akrilik [jurnal].FakultasKedokteran Gigi UniversitasHasanudin, Makasar;

Manfaat Air Liur. [diakses 03 november 2015] Tersedia dari URL : http://klinikpengobatanalami.wordpress.com/2013/08/28/manfaat-air-liur/

Nisa, Rosidatun. 2013, Perbandingan Daya Hambat Rebusan Dan Perasan Bunga Rosella Merah (Hibiscus sabdariffa L.) Terhadap Pertumbuhan Bakteri Staphylococcus aureus dan Escherichia coli [sumber online] 19 Desember 2013 [diakses 8 November 2014]. Tersedia dari : URL http://hdl.handle.net/123456789/10569

Prestiyanti, Ni Made Ista. 2014, Efektivitas Berkumur dengan Larutan Teh Rosella (Hibiscus Sabdariffa L.) Mempercepat Penyembuhan Gingivitis Pasca Skeling [skripsi]. Denpasar : Program Studi Fakultas Kedokteran Gigi Universitas Mahasaraswati Denpasar;

Sari, Indah Permata. 2014, Efektivitas Obat Kumur Ekstrak Bunga Rosela Dalam Menghambat Pertumbuhan Plak [skripsi]. Fakultas Kedokteran Gigi Universitas Sumatera Utara;

SofrataAH. 2010, Salvadorapersica (Miswak) an effective way of killing oral pathogens[disertasi]. Stockholm (Sweden): Karolinska Institute; 